\title{
Management of Market Pelita Retribution In Bangko District In Increasing Original Revenue of Rokan Hilir Regency
}

\author{
Dona Doni ${ }^{1}$, Moris Adidi Yogia ${ }^{2}$, Zainal $^{3}$, Muhd Ar. Imam Riauan ${ }^{4}$, \\ Astri Ayu Purwati ${ }^{5}$ Made Devi Wedayanti ${ }^{6}$ \\ Universitas Islam Riau ${ }^{12346}$, Institut Bisnis dan Teknologi Pelita Indonesia ${ }^{5}$ \\ doni.dona44@yahoo.co.id ${ }^{1}$, moris.adidiy@soc.uir.ac.id², zainal.ip@soc.uir.ac.id ${ }^{3}$, \\ imamriauan@comm.uir.ac.id ${ }^{4}$, astri.ayu@lecturer.pelitaindonesia.ac.id ${ }^{5}$ and \\ madedeviwedayanti@soc.uir.ac.id ${ }^{6}$
}

\begin{abstract}
Market Retribution is one source of Regional Original Income which has the potential to provide the largest input to the regional treasury. For this reason, the Regional Government of Rokan Hilir Regency continues to strive to manage market retribution services. However, the problems that occur in the Pelita Market in Bangko District based on the realization of the target market retribution received do not significantly affect Regional Original Income. purpose of this study was to analyze the Management of the Pelita Market Retribution in Bangko District in increasing the Regional Revenue of Rokan Hilir Regency. This type of research is quantitative research and descriptively describes facts, circumstances, variables, and phenomena that occur. The population of this study is that government officials carry out administrative services on the Pelita market in Bangko District and the Pelita Market traders in Bangko Sub-District, totaling 109 people. Data was collected by questionnaires and research interviews. The results showed that: the management of Pelita Market Retribution in Bangko District was in a fairly good category, because there were still various natural problems in managing the Pelita market retribution in Bangko Sub-district carried out by the Office of Industry, Trade and Market in Rokan Hilir Regency.
\end{abstract}

Keywords: Market Levy Management, Regional Original Revenue.

\section{Introduction}

Regional Original Income is a picture of the potential of regional finance in general, which is more dominant than relying on regional financial revenue through local tax revenues and regional levies. Associated with Regional Original Revenues sourced from local taxes and levies, the region can explore the full potential of existing regional resources. Regional levies are principally managed by each region, because in the effort to manage local user fees there may be different systems or methods used by each region. One form of regional levies is Market Service Levies. However, in optimizing regional revenue sourced from the local retribution, the biggest problem that can hamper the optimization of regional acceptance is the quality factor of human resources (HR) as well as the regional managerial ability to manage the Regional Tax and Retribution. This condition will certainly directly impact on the non-optimism of blood 
revenues through regional taxes and charges. On the other hand, having established regional autonomy requires local governments to be able to fund various government and development activities on their own. This means that regions no longer depend on funds or subsidies from the central government, where the amount is very limited for some regions. For this reason, the regional government is currently demanded to be able to manage regional revenue sources effectively and efficiently. Market levies in the regency are very volatile and contribute an average annual contribution of $1.82 \%$, the growth of the average contribution each year decreases by $14.4 \%$, revenue from market levies can potentially increase rapidly, but the increase is not too sharp because Y (acceptance of market retribution realization) from 20072014 also experienced a rise that was not too sharp either, thus affecting the market retribution trend in the years to come [1]. to find out the potential market levies for increasing the original income of the Lamongan Regency. From the research results it is known that the potential market levies on increasing PAD, from the calculation results it is known that the realization of Market Retribution is very far apart that is always below the potential. These results are obtained based on available data, so that revenue that should be better bias is reduced because the implementation of market levies is considered still not optimal. So the potential acceptance of market levies is still considered to be less potential [2].

From the levies levied by the Regional Government of Rokan Hilir Regency, which when levied by the Regional Government of Rokan Hilir Regency are through market levies. With the growing population and economic level of the community, pasa levies are expected to make a large contribution to regional revenue in Rokan Hilir Regency. In order to increase market retribution, the quality of service to the community, both for consumers consisting of buyer communities or traders who are sources of regional income through market fees must also be improved. There are currently 25 markets in Rokan Hilir that contribute to Local Revenue. The 25 markets consist of 802 Kiosks, 83 Loss and 1945 stalls. Targets and realization of the target of receiving market levy funds in Rokan Hilir Regency will be explained in table 1. below:

Table 1. Targets and Realization of Targets for Market Retribution in Rokan Hilir Regency in 2016-2018

\begin{tabular}{ccccc}
\hline No. & Year & Targets & Realisation & Persentage \\
\hline 1 & 2016 & Rp. 100.000.000,00 & Rp. 151.500.000,00 & $151,50 \%$ \\
2 & 2017 & Rp. 110.000.000,00 & Rp. 128.563.000,00 & $116,88 \%$ \\
3 & 2018 & Rp. 120.000.000,00 & Rp. 143.850.000,00 & $119,88 \%$ \\
& Avarage & & $129,42 \%$ \\
\multicolumn{7}{l}{ Source: Rokan Hilir Regency Industry and Trade and Market Office (data processed) }
\end{tabular}

Based on the data in table 1. above, it is known that the management of market levies carried out by the Department of Trade and Market Industry of Rokan Hilir Regency shows that the target and realization of the target of receiving market levies in Rokan Hilir Regency in 20162018 have reached the established target with the average percentage value $129.42 \%$. But in reality the realization of the target market revenue levies, does not significantly affect the increase in Local Revenue in Rokan Hilir Regency, because the percentage of the contribution of regional revenue through market service fees in the Rokan Hilir District is very small with an average value over the last three years ie from 2016 up to 2018 , only around $0.101 \%$ of the total Local Revenue in Rokan Hilir Regency. Data on the percentage of recipient contributions from Market Levies in Rokan Hilir Regency, will be explained in table 1.4 Contribution of Market Service Levies to the Original Revenue of Rokan Hilir Regency below as follows: 
Table 2. Contribution of Market Service Retribution to Original Revenue of Rokan Hilir Regency

\begin{tabular}{|c|c|c|c|c|}
\hline No & Year & Market Levy Receipt & Locally-generated revenue & Percentage of Contributions \\
\hline 1 & 2016 & Rp. 151.500.000,00 & Rp. 179.187.169.328,00 & $0,08 \%$ \\
\hline 2 & 2017 & Rp. $128.563 .000,00$ & Rp. 111.176.179.123,00 & $0,12 \%$ \\
\hline 3 & 2018 & Rp. $143.850 .000,00$ & Rp. 106.204.207.220,00 & $0,14 \%$ \\
\hline \multicolumn{4}{|c|}{ Avarage } & $0,34 \%$ \\
\hline
\end{tabular}

Source: Rokan Hilir Regency Industry and Trade and Market Office (data processed)

Based on the data in table 2. above it is known that the contribution of Rokan Hilir Regency revenue that originates from market levies is very small, with an average value of $0.34 \%$. From the results of the initial survey of the research obtained information that not all markets in Rokan Hilir Regency contribute to the Original Regional Revenue. At present there are 58 markets in Rokan Hilir Regency. But from the data it is known that only 25 markets whose market retribution funds are managed and deposited to the local treasury of Rokan Hilir Regency. While 33 other markets did not contribute or enter market retribution funds to the Rokan Hilir district government treasury. This shows that in general the management of market levies in Rokan Hilir Regency has not been carried out properly.

\section{Literature Review}

Management is a special ability and skill to carry out an activity both with others, or through others in achieving organizational goals[3]. States that management (management) is a set of roles carried out by a person or group of people, or it can also refer to functions attached to that role[4]. Sumijo and Soebedjo in Sudjana argued that: "Management is the process of planning, organizing, leading and controlling the efforts of organizing members and using all other organizational resources to achieve stated organizational goals" If we examine the two senses above, it turns out that the implementation of this understanding is: management is a series of activities to plan, organize, move, control and develop in an innovative way to all efforts in managing and utilizing human resources, facilities and infrastructure effectively and efficiently to achieve organizational goals that have been set[5]. Fattah argues that in a management process the main functions involved are performed by a manager or leader, namely planning (planning), organizing (organizing), leaders (leading), and supervision (controlling). Therefore, management is defined as the process of planning, organizing, leading, and controlling the efforts of the organization with all its aspects so that organizational goals are achieved effectively and efficiently[6].

Regional Original Income according to constitutes all regional income originating from regional original economic sources[7]. Efforts to increase PAD positively in the sense that freedom by the regions must be utilized to increase PAD to explore new sources of revenue without burdening the community and without creating a high-cost economy. Efforts to increase PAD must be seen as a manifestation of the responsibility of local governments to improve services and public welfare. The Regional Original Revenue is a purely regional source consisting of: Regional Revenue, Regional Retribution, Results of Separated Regional Wealth Management and Other Legitimate Regional Original Revenues[8]. The definition of regional levies according to Law No. 28 of 2009 is a regional levy as payment for services or granting 
certain licenses specifically provided and or given by the regional government for the benefit of individuals or entities. According to Rokan Hilir District Regulation Number 21 of 2011 concerning Market Service Levies in article 1 paragraph 15 it is stated that Market Service Levies hereinafter referred to as market levies are payments for providing traditional / simple market facilities in the form of equipment, stalls and or kiosks managed by the government and provided Trading does not include those managed by regional government-owned companies and private parties. Market levies also have the same object as other public service fees, namely services provided or provided by local governments for the purpose of public interest and benefit and can be enjoyed by individuals or groups. The object of market service levies is based on Rokan Hilir District Regulation No. 21 of 2011 concerning Market Service Retribution, it is stated that the object of retribution is the provision of market, traditional / simple facilities in the form of equipment, booths and / or kiosks managed by the government and provided to traders, excluding those managed by the Regional Government and specifically provided for traders

\section{Methodology}

This type of research is quantitative research that is research that emphasizes numerical data (numbers) that are processed by statistical methods[9]. Quantitative research in terms of objectives, this research is used to test a theory, present a fact or describe statistics, and to show the relationship between variables and those who develop concepts, develop understanding or describe many things[10] . The specification of this research is descriptive in nature, namely to raise the facts, circumstances, variables, and phenomenons that occur now (when the research takes place) and the presentation is as is. This research is research that leads to correlational studies. With this method the researcher will describe the Management of the Pelita Market Levy in Bangko District in Increasing the Original Revenue of the Rokan Hilir District. This study took two locations, namely Pelita Market, Bangko District, Rokan Hilir Regency and the Department of Trade Industry and Market, Rokan Hilir Regency. The population in question is the government apparatus in charge of carrying out administrative services in the Pelita Kecamatn Bangko market and traders selling at the Pelita market in Bangko District, Rokan Hilir Regency. The number of samples in this study as many as 109 people, where this number consists of is the total number of employees of the Office of Industry and Trade and Rokan Hilir Regency and traders selling in Pasar Pelita market, Bangko District, Rokan Hilir District. The methodology of this research is non-experimental research conducted using a descriptive method approach and data collection using survey methods.

\section{Results and Discussion}

To provide an overview of the Management of the Pelita Market Levy in Bangko District in Increasing the Original Revenue of the Rokan Hilir Regency, this section will provide a description of each variable based on respondents' responses to the research questionnaire items. The results of respondent responses totaling 109 people, based on the results of the research questionnaire will be described in the form of a frequency tabulation table with scores for each dimension variable as follows : 
4.1 An Analysis of the Management of the Pelita Market Levy in Bangko District in Increasing the Original Revenue of the Rokan Hilir District

Rokan Hilir Regency Market Service Retribution is one type of retribution that has a high enough potential to increase its acceptance. But in reality, the contribution of revenue from Market Retribution in Rokan Hilir Regency can be said to be still not maximal, it can be seen from the data on the realization of market retribution revenue in 2016-2018. and it is known that the contribution of Rokan Hilir Regency revenue which originated from the Market Service Levy for three years from 2016 to 2018 is very small, with an average value of $0.34 \%$, with such a small contribution, the Rokan Hilir Regency government stipulates Rokan Hilir Regency Number 21 Year 2011 Regarding Market Service Levies as an effort to optimize revenue from the levy sector. In this study, the management of Market Levy is assessed based on management functions according to Terry in Gie (2000: 21), which states that the activities or management functions, include: Planning, Organizing, Actuating and Controlling. Based on the results of research on the variable Pelita Market Retribution Management in Bangko District in Increasing Local Revenue of Rokan Hilir Regency.

4.2 Analysis of Variable Planning Dimensions in the Management of Pelita Market Levies in Bangko District in Increasing Local Revenue of Rokan Hilir Regency

Based on the results of the distribution of research questionnaires regarding the variable dimensions of Planning Management of the Pelita Market Levy in Bangko District in Increasing the Original Revenue of the Rokan Hilir Regency, will be explained in table 3. below as follows:

Table 3. Analysis of Variable Planning Dimensions in the Management

\begin{tabular}{lcccccccc}
\hline No & Item Questions & \multicolumn{4}{c}{ Assessment Criteria } & & Total & Category \\
& & SB & B & CB & KB & TB & & \\
\hline 1 & Target acceptance Planning & 0 & 64 & 43 & 2 & 0 & 109 & Good \\
2 & Action taken & 2 & 66 & 35 & 6 & 0 & 109 & \\
3 & Implementation team & 4 & 33 & 39 & 33 & 0 & 109 & \\
& performance & & & & & & & \\
& Number of Responses & 6 & 163 & 117 & 41 & 0 & 327 & \\
& Total score & 30 & 652 & 351 & 82 & 0 & 1115 & \\
& Percentage & 1.83 & 49.85 & 35.78 & 12.54 & 0 & 100 & \\
& & &
\end{tabular}

Source: Processed Research Data 2019

Based on the data in table 3. above, it can be seen that the Planning of Pelita Market Levy Management in Bangko District in Increasing Original Revenue of Rokan Hilir Regency according to most of the highest average research respondents is in the Good category, namely 163 responses or $49.85 \%$ of the total responses of research respondents.

4.3 Analysis of the Organizing Variable Dimension Management of the Pelita Market Retribution in Bangko District in Increasing the Original Revenue of Rokan Hilir District

Based on the results of the distribution of research questionnaires regarding the variable dimensions Organizing Management of Pelita Market Levy in Bangko District in Increasing 
Original Revenue of Rokan Hilir Regency, will be explained in table 4. below as follows:

Table 4. Analysis of the Organizing Variable Dimension Management

\begin{tabular}{|c|c|c|c|c|c|c|c|c|}
\hline \multirow[t]{2}{*}{ No } & \multirow[t]{2}{*}{ Item Questions } & \multicolumn{5}{|c|}{ Assessment Criteria } & \multicolumn{2}{|c|}{ Total Category } \\
\hline & & SB & B & CB & KB & TB & & \\
\hline 1 & $\begin{array}{l}\text { Organizational resource } \\
\text { capabilities }\end{array}$ & 3 & 32 & 65 & 9 & 0 & 109 & $\begin{array}{c}\text { Good } \\
\text { Enough }\end{array}$ \\
\hline 2 & $\begin{array}{l}\text { The ability of the leadership of the } \\
\text { organization }\end{array}$ & 1 & 56 & 47 & 5 & 0 & 109 & \\
\hline 3 & $\begin{array}{l}\text { Implementation of organizational } \\
\text { roles }\end{array}$ & 1 & 16 & 42 & 50 & 0 & 109 & \\
\hline & Number of Responses & 5 & 104 & 154 & 64 & 0 & 327 & \\
\hline & Total score & 35 & 416 & 462 & 128 & 0 & 1031 & \\
\hline & Percentage & 1.53 & 31.80 & 47.09 & 19.57 & 0 & 100 & \\
\hline
\end{tabular}

Source: Processed Research Data 2019

Based on the data in table 4. above, it can be seen that the Management of Pelita Market Retribution in Bangko Subdistrict in Increasing Original Revenue of the Rokan Hilir Regency based on the Organizing variable dimension according to most of the research respondents, the highest average is in the Good Enough category, namely 154 responses or $47,09 \%$ of the overall research respondents' responses. Based on the results of the study and also observations / observations that have been made at the Office of Industry and Trade Industry and Market Rokan Hilir District and also at the location of the Pelita market Bangko District regarding Organizing (Organizing) in managing the Pelita market retribution, actions taken in an effort to achieve the target of receiving retribution as well as the performance of the administrators of the Pelita market service levies in Bangko District are in the Pretty Good category. This shows that the Department of Trade and Market Industry of Rokan Hilir Regency as an institution managing Pelita market service levies has not been able to carry out its functions properly.

4.4 Analysis of the Actuating Variable Dimension (Implementation / Mobilization) in the Management of the Market Pelita Retribution in Bangko District in Increasing Original Revenue of Rokan Hilir District

Based on the results of the distribution of research questionnaires regarding the dimensions of the Actuating variable (Implementation / Mobilization) Management of Market Pelita Retribution in Bangko District in Increasing Original Revenue of Rokan Hilir Regency, will be explained in table 5. below as follows:

Table 5. Analysis of the Actuating Variable Dimension (Implementation / Mobilization) in the Management

\begin{tabular}{lccccccc}
\hline No Item Questions & \multicolumn{9}{c}{ Assessment Criteria } & Total Category \\
& SB & B & CB & KB & TB & & \\
\hline $\begin{array}{l}\text { 1 Work motivation by the } \\
\begin{array}{l}\text { Weadership } \\
\text { leadersh }\end{array}\end{array}$ & 51 & 49 & 9 & 0 & 109 & $\begin{array}{c}\text { Good } \\
\text { Enough }\end{array}$ \\
\hline
\end{tabular}




\begin{tabular}{|c|c|c|c|c|c|c|c|}
\hline \multirow[t]{2}{*}{$\overline{\text { No }}$} & \multirow[t]{2}{*}{ Item Questions } & \multicolumn{5}{|c|}{ Assessment Criteria } & \multirow[t]{2}{*}{ Total Category } \\
\hline & & SB & B & CB & KB & TB & \\
\hline & $\begin{array}{l}\text { Coordinating } \\
\text { management tasks }\end{array}$ & 1 & 52 & 44 & 9 & 3 & 109 \\
\hline 3 & $\begin{array}{l}\text { Meeting the needs of } \\
\text { employees and traders }\end{array}$ & 0 & 6 & 44 & 45 & 14 & 109 \\
\hline & Number of Responses & 1 & 109 & 137 & 63 & 17 & 327 \\
\hline & Total score & 5 & 436 & 411 & 126 & 17 & 995 \\
\hline & Percentage & 0.31 & 33.33 & 41.90 & 19.27 & 5.2 & 100 \\
\hline
\end{tabular}

Based on the data in table 5. above it can be seen that the Management of Pelita Market Retribution in Bangko Subdistrict in Increasing Original Revenue of Rokan Hilir Regency based on the dimension of Actuating variable according to most of the highest average research respondents were in the Good Enough category, namely 137 responses or $41.90 \%$ of the overall responses of research respondents.

\subsection{Analysis of Variable Controlling (Supervision) Management of Market Pelita Market Levy in Bangko District in Increasing Original Revenue of Rokan Hilir Regency}

Based on the results of the distribution of research questionnaires regarding the Controlling variable (Supervision) Management of the Pelita Market Levy in Bangko District in Increasing the Original Revenue of the Rokan Hilir Regency, will be explained in table 6. below as follows:

Table 6. Respondents Response Against the Dimension Variable Controlling (Supervision) Management of Market Pelita Retribution in Bangko District in Increasing Local Revenue of Rokan Hilir Regency

\begin{tabular}{ccccccccc}
\hline No & Item Questions & \multicolumn{9}{c}{ Assessment Criteria } & Total & Category \\
& & SB & B & CB & KB & TB & & \\
\hline 1 & Direct supervision & 3 & 63 & 36 & 6 & 1 & 109 & Good \\
2 & Indirect supervision & 3 & 55 & 51 & 0 & 0 & 109 & \\
& Number of Responses & 6 & 118 & 87 & 6 & 1 & 218 & \\
& Total score & 30 & 436 & 411 & 126 & 17 & 995 & \\
& Percentage & 0.31 & 33.3341 .90 & 19.27 & 5.2 & 100 & \multicolumn{5}{c}{ Source: Processed Research Data 2019 }
\end{tabular}

Based on the data in table 6. above, it can be seen that the Management of Pelita Market Retribution in Bangko Subdistrict in Increasing Original Revenue of Rokan Hilir Regency based on the Controlling Variable dimension (supervision) according to most of the respondents the highest average research is in the Good category, namely 118 responses or $54.13 \%$ of the overall responses of study respondents.

4.6 Recapitulation of Respondents' Responses Regarding Variable Management of Market Pelita Retribution in Bangko Subdistrict in Increasing Original Revenue of Rokan Hilir District 
Table 7. Recapitulation of Respondents' Responses

\begin{tabular}{llccccccc}
\hline No & Item Questions & \multicolumn{4}{c}{ Assessment Criteria } & \multicolumn{3}{c}{ Total Category } \\
& & SB & B & CB & KB & TB & \\
\hline 1 & Planning & 6 & 163 & 117 & 41 & 0 & 327 & Good \\
2 & Organizing & 5 & 104 & 154 & 64 & 0 & 327 & Enough \\
3. & Actuating & 1 & 109 & 137 & 63 & 17 & 327 & \\
4. & Controling & 6 & 118 & 87 & 6 & 1 & 218 & \\
& $\quad$ Number of Responses & 18 & 494 & 495 & 174 & 18 & 1199 & \\
& $\quad$ Total score & 90 & 1976 & 1485 & 348 & 18 & 3917 & \\
& $\quad 1.50$ & 41.20 & 41.28 & 14.51 & 1.50 & 100 & \\
& Percentage & & \multicolumn{5}{c}{ Source: Processed Research Data 2019 }
\end{tabular}

Based on the research data obtained in table 5.12 above, it can be seen the actual score (total score obtained) from the responses of respondents amounted to 3917 in the category of Good Enough.

\section{Conclusion}

Based on the recapitulation of research data obtained from the distribution of questionnaires conducted on 109 research samples, it is known that the Management of Pelita Market Retribution in Bangko District in Increasing the Original Revenue of Rokan Hilir Regency is in the Fairly Good category. From the observations of researchers that have been carried out and also from the results of the distribution of research questionnaires it is known that the Management of Market Pelita Retribution in Bangko District in Increasing Original Revenue of Rokan Hilir Regency has not been carried out properly, because there are still a variety of factors that lead to market service levies in the Pelita Market in Rokan Regency Hili cannot meet the targets set by the Regional Government of Rokan Hilir Regency, among others: in terms of the number of apparatus in charge or the expertise possessed by market management levies management officers is inadequate, the role of the Rokan Hilir Regency Industry, Trade and Market Office in the management of Retribution Pasar Pelita of Bangko District has not been held well, because there are still a large number of street vendors selling outside the market area that cannot be controlled by market managers. There is no incentive for market levies (iner) collected by the Regional Government of Rokan Hilir Regency, due to lack of funding. There is no incentive for market levies (iner) collected by the Regional Government of Rokan Hilir Regency, due to lack of funding. Not implementing administrative sanctions against traders who cannot pay on time or underpaid according to Rokan Hilir District Regulation Number 21 of 2011 concerning Market Service Retribution and Not optimal implementation of supervision carried out by the Department of Industry, Trade and Market of Rokan Hilir Regency as manager market levies of the Pelita District of Bangko on tickets that have been distributed by the levies collection officers to traders

\section{Acknowledgements}

This study is Research Grants by The Ministry of Research and Technology/the National Agency for Research and Innovation of the Republic of Indonesia year 2020. 


\section{References}

[1] Megawati, N. A. Kontribusi Retribusi Pasar Terhadap Pendapatan Asli Daerah (Pad) Kabupaten Sidoarjo. Vol. 3 No. 2, Jurnal Pendidikan Ekonomi (JUPE), (2016).

[2] Handayani, S. Potensi Retribusi Pasar terhadap Peningkatan Pendapatan Asli Daerah (PAD) Kabupaten Lamongan. Vol 2 No. 1, pp. 247-370, Jurnal Penelitian Ekonomi dan Akuntansi,. (2017).

[3] Muflichana, N. Manajemen kurikulum pondok pesantren (studi kasus di Pondok Pesantren Putri Aris Kaliwungu Kendal, Doctoral dissertation, UIN Walisongo, (2016).

[4] Suharto, S. Studi Tentang Keamanan dan Keselamatan Pengunjung Hubungannya dengan Citra Destinasi (Studi Kasus Gembira Loka Zoo). Vol. 14, No. 1, Media Wisata, (2016).

[5] Arfandi, A. Spiritualitas Kepemimpinan dalam Pengelolaan Pendidikan dan Pembelajaran. Vol. 4, No. 1, pp. 50-65.Jurnal Pendidikan Islam Indonesia, (2019).

[6] Virtaharju, J. J., \& Liiri, T. P. The supervisors who became leaders: Leadership emergence via changing organizational practices. Vol. 15, No.1, pp. 103-122, Leadership, (2019).

[7] Saputra, K. A. K., Sara, I. M., Jayawarsa, A. K., \& Pratama, I. G. S. Management of Village Original Income in The Perspective of Rural Economic Development. Vol. 1, No. 2, pp. 5259.International Journal of Advances in Social and Economics, (2019).

[8] Sulastri, L., \& Nugraha, P. Supervision of Hotel and Restaurant Tax Learning to Improve Regional Original Income (PAD) Sumedang District. Vol. 2, No. 1, pp. 13-23, Journal of Economic Empowerment Strategy (JEES), (2019).

[9] Thomann, E., \& Maggetti, M. Designing research with qualitative comparative analysis (QCA): Approaches, challenges, and tools. Vol. 49, No. 2, pp. 356-386, Sociological Methods \& Research, (2020).

[10] Riffe, D., Lacy, S., Fico, F., \& Watson, B. Analyzing media messages: Using quantitative content analysis in research, Routledge, (2019). 